\section{Radioprotective Effects of Dimethyl Sulfoxide Vapor on Mice}

Dimethyl sulfoxide (DMSO) has produced considerable interest in its biological applications as a radioprotective agent in the last few years ${ }^{1-5}$. Several of these findings have been confirmed by HIGHMAN and co-workers ${ }^{8}$. There is to date no adequate explanation for the radioprotective action of DMSO, or for that matter of tryptamine, 5-HT (serotonin), ATP etc. On the other hand, chlorpromazine with its numerous sulfoxides lacks antiradiation protective properties.

Recently the radioprotective effects of DMSO applied topically to the tails of mice was reported by the authors? and a dose reduction factor of about 1.3-1.4 was found in subsequent experiments ${ }^{8}$. Further results of these studies, and in particular, the effects on the weights of irradiated mice have been collected. The findings support the general picture of the mortality studies, that the DMSOtreated animals showed a lesser weight loss ${ }^{9}$. Also, some indications as to the effectiveness of this chemical in irradiated mice has been found in saccharin avoidancebehavior tests ${ }^{10}$.

These increasingly interesting and promising findings led us to further experimentation with DMSO and dissolved chemicals, exposing mice before and during irradiation to DMSO vapor, and also to vapors of various chemicals dissolved in this solvent (DMSO).

Methods. The animals were exposed in a two-level cage to the vapors and radiation. Ten mice in individual compartments could be treated simultaneously in this manner, while one compartment of the cage was reserved for a Victoreen Condenser R-meter. Three groups of mice were subjected to X-rays, generated by a $400 \mathrm{KV}$ Maxitron with $0.5 \mathrm{~mm} \mathrm{Cu}+1.0 \mathrm{~mm}$ Al. Filtration, at a target-mouse distance of $50 \mathrm{~cm}$ and a dose rate of 80 $\mathrm{R} / \mathrm{min}$. The cage was rotated at $2.5 \mathrm{rpm}$. In the first group of 80 animals the bottom part of the cage unit contained $100 \mathrm{ml}$ of water, and this group served as a control experiment. These mice received a total exposure dose of $850 \mathrm{R}$. The second group of 60 mice was identically treated, except that the water was replaced by $100 \mathrm{ml}$ of DMSO $(100 \%)$, and the mice received an X-ray dose of $900 \mathrm{R}$. In the third group, the irradiation dosage given to the animals was also $900 \mathrm{R}$, but here the bottom part of the cage contained $7 \mathrm{~g}$ of Nembutal dissolved in $100 \mathrm{ml}$ DMSO. No physical contact with the solutions was possible by the animals except for the vapor carried through small ventilating holes (1/8 inch dia.) in the flooring. Fresh air mixed with the vapor was carried simply by convection from the lower level of the cage to the upper level where the animals were kept, and exhausted through the holes in the cage top cover. Actual vapor concentrations were not determined at this time. Immediately after the treatment, the mice were returned to their original community cages filled with saw-dust, and food and water made available ad libitum. Male $\left(\mathrm{CF}_{1}\right)$ mice were employed throughout all these experiments.

Results and discussion. We have previously reported the protective effect against $\mathrm{X}$-irradiation of DMSO when topically applied to the tails of otherwise untreated mice.

For the first time, we now report the protective effect against $\mathrm{X}$-radiation of DMSO vapor alone, or in combination with dissolved Nembutal. The control animals $\left(\mathrm{H}_{2} \mathrm{O}\right)$ always died faster than those inhaling the vapor-air mixture rising from the $100 \mathrm{ml}$ of DMSO placed in the bottom part of the irradiation cage. This is further emphasized by the fact that the DMSO groups received a radiation dose which was $50 \mathrm{R}$ larger than that given to the control groups. An even greater change was noticed in those animal groups which were exposed to a mixture of air and DMSO + Nembutal. Again a $50 \mathrm{R}$ larger X-ray dose was received by these animals in comparison with the controls. The experimental data are presented in the Table.

We are in the process of developing vapor concentration measuring techniques that are suitable for evaluating experimental dose reduction factors in similar studies, and the changes in mortality distribution at lower dosages. There are some preliminary indications presenting a shift in the mortality peaks, particularly those concerning the DMSO + Nembutal groups, which may be fruitful in elucidating the unknown protective mechanisms associated with, or involving these chemicals 11.

Comparative survival times of irradiated mice (\%) exposed to vapors of (1) $\mathrm{H}_{2} \mathrm{O}$, (2) DMSO, (3). DMSO + Nembutal

\begin{tabular}{|c|c|c|c|}
\hline $\begin{array}{l}\text { Post- } \\
\text { irradiation } \\
\text { (days) }\end{array}$ & $\begin{array}{l}\% \mathrm{H}_{2} \mathrm{O} \\
\text { (80 mice) } \\
\text { control } \\
(850 \mathrm{R})\end{array}$ & $\begin{array}{l}\%(60 \text { mice }) \\
\text { DMSO } \\
(900 \mathrm{R})\end{array}$ & $\begin{array}{l}\% \text { (60 mice) } \\
\text { DMSO + } \\
\text { Nembutal } \\
(900 \mathrm{R})\end{array}$ \\
\hline 1 & 100 & 100 & 100 \\
\hline 2 & 100 & 100 & 100 \\
\hline 3 & 100 & 100 & 100 \\
\hline 4 & 95 & 100 & 98 \\
\hline 5 & 82 & 95 & 97 \\
\hline 6 & 64 & 85 & 93 \\
\hline 7 & 42 & 60 & 88 \\
\hline 8 & 32 & 52 & 77 \\
\hline 9 & 25 & 43 & 55 \\
\hline 10 & 17 & 30 & 27 \\
\hline 11 & 6 & 12 & 13 \\
\hline 12 & 1 & 3 & 7 \\
\hline 13 & 1 & 2 & 5 \\
\hline 14 & 0 & 0 & \\
\hline 15 & 0 & 0 & \\
\hline
\end{tabular}

Zusammenfassung. Versuche mit röntgenbestrahlten Mäusen ergaben, dass durch Anwendung von Dimethyl Sulfoxid (DMSO gasförmig) sowie $7 \%$ iger Lösung von Nembutal in DMSO (ebenfalls gasförmig) die Msortalitä bedeutend herabgesetzt wird.

W. S. Moos, H. LEVAN and H. C. MASON

University of Illinois College of Medicine, Chicago (Illinois 60680) and Arkansas State Hospital, Little Rock (Arkansas 72207, USA), 1 st June 1967.

1 M. J. Ashwood-Smith, Int. J. Radiat. Biol. 3, 41 (1961).

M. J. Ashwood-SmIth, Ann. N.Y. Acad. Sci. 74t, 45 (1967),

O. Vos and M. C. A, KAALEN, Int. J. Radiat. Biol. 5, 621 (1962).

4. MeER, P. W. VAlkenBURg and M. Remmelts, Int. J. Radiat. Biol. 6, 151 (1963).

- F. Gallan, Ann. N.Y. Acad. Sci. 141, 63 (1967).

B. Highman, J. R. Hanselt and D. C. White, Radiat. Res. 30 , 563 (1967).

"W. S. Moos and S. E. Kim, Experientia 22, 814 (1966).

W. S. Moos and S. E. Krm. Presented at the Radiological Soc. of North America, November 1966, and in print (Radiology).

- S. E. Krm and W. S. Moos, J. Hith Phys., in print.

10 H. LEVAN and W. S. Moos, Experientia 23, 276 (1967).

11 This work was supported in part by a grant of the University of Illinois Foundation No. 2-46-33-90-3-10. 